\title{
The percentage of macrophage numbers in rat model of sciatic nerve crush injury
}

\author{
Satrio Wicaksono ${ }^{1}$, Muhammad Ghufron ${ }^{2}$, Rina Susilowati ${ }^{2 *}$ \\ ${ }^{1}$ Universitas Halu Oleo, Kampus Hijau Bumi Tridharma Andounohu, Kendari, Southeast \\ Sulawesi, ${ }^{2}$ Departement of Histology and Cell Biology, Faculty of Medicine, Universitas \\ Gadjah Mada, Yogyakarta
}

DOI: http://dx.doi.org/10.19106/JMedSci004701201501

\begin{abstract}
Excessive accumulation of macrophages in sciatic nerve fascicles inhibits regeneration of peripheral nerves. The aim of this study is to determine the percentage of the macrophages inside and outside of the fascicles at the proximal, at the site of injury and at the distal segment of rat model of sciatic nerve crush injury. Thirty male 3 months age Wistar rats of 200-230 g were divided into sham-operation group and crush injury group. Termination was performed on day 3,7 , and 14 after crush injury. Immunohistochemical examination was done using anti CD68 antibody. Counting of immunopositive and immunonegative cells was done on three representative fields for extrafascicular and intrafascicular area of proximal, injury and distal segments. The data was presented as percentage of immunopositive cells. The percentage of the macrophages was significantly increased in crush injury group compared to the sham-operated group in all segments of the peripheral nerves. While the percentage of macrophages outside fascicle in all segments of sciatic nerve and within the fascicle in the proximal segment reached its peak on day 3 , the percentage of macrophages within the fascicles at the site of injury and distal segments reached the peak later at day 7 . In conclusions, accumulation of macrophages outside the nerve fascicles occurs at the beginning of the injury, and then followed later by the accumulation of macrophages within nerve fascicles.
\end{abstract}

\section{ABSTRAK}

Akumulasi makrofag yang berlebihan di dalam fasikulus nervus ischiadicus dapat menghambat regenerasi saraf tepi. Tujuan dari penelitian ini adalah untuk mengetahui persentase makrofag di dalam maupun di luar fasikulus pada segmen proksimal, segmen cedera dan segmen distal setelah terjadi cedera kompresi akut pada nervus ischiadicus. Tiga puluh ekor tikus Wistar jantan usia 3 bulan dengan berat badan 200-230 gr, dibagi menjadi kelompok sham-operation dan kelompok cedera kompresi. Terminasi dilakukan pada hari ke-3, hari ke-7, dan hari ke-14 setelah cedera kompresi. Pemeriksaan imunohistokimia dilakukan dengan menggunakan antibodi anti CD68 (ED1). Pengamatan dilakukan pada tiga lapangan pandang oleh dua orang pengamat. Data disajikan dalam bentuk rerata persentase sel imunopositif. Jumlah makrofag pada kelompok cedera kompresi meningkat secara bermakna di banding kelompok sham-operation pada semua segmen saraf tepi. Jumlah makrofag tertinggi pada segmen proksimal di dalam fasikulus teramati pada hari ke-3. Jumlah makrofag tertinggi pada segmen cedera dan distal di dalam fasikulus teramati pada hari ke- 7 , sedangkan jumlah makrofag di luar fasikulus meningkat pada hari ke- 3 di semua segmen nervus ischiadicus. Dapat disimpulkan, akumulasi makrofag di luar

\footnotetext{
* corresponding author: rina_susilowati@yahoo.co.id
} 
fasikulus terjadi pada awal cedera, kemudian setelah itu makrofag terakumulasi di dalam fasikulus untuk memfagositosis debris myelin.

Keywords: macrophages - crush injury - sciatic nerve - peripheral nerve fascicles

\section{INTRODUCTION}

Peripheral nerve injury can be caused by traumatic process (for example due to an accident), tumor suppression, surgery, or disease processes such as diabetes mellitus and infections..$^{1-4}$ Nerve injury is followed by Wallerian degeneration process of the distal segment, which involves a series of processes that initiated by the dedifferentiation and proliferation of Schwann cells. Schwann cells release cytokines such as TNF- $\alpha$, IL- $1 \alpha$ and chemokines such as monocyte chemoattractant protein-1 (MCP-1), macrophage inflammatory protein-1 $\alpha$ (MIP-1 $\alpha)$ which causes the migration of macrophages from circulation. Furthermore, macrophages release similar proinflammatory cytokines to induce the phagocytosis of the debris in order to create a conducive environment for the regeneration process. ${ }^{3,5-14}$

The study on macrophages response to peripheral nerves injury was performed using several models, such as transection ${ }^{15}$, crush injury $^{16,17}$, and partial ligation ${ }^{18}$. Macrophages mediate the proinflammatory reaction and regeneration within the fascicles. Macrophages induce the production of several proinflammatory cytokines such as TNF- $\alpha$, IL-1 and IL-6 which is useful in induction of myelin debris clean up and provide space for subsequent regeneration process. However, there is a report that the accumulation of macrophages in significant number can inhibit nerve regeneration. ${ }^{19,20}$

Macrophages are accumulated after injury either inside or outside the nerve fascicles.
Their number inside and outside the nerve fascicles of the distal segment have been shown to be increase after nerve transection injury. ${ }^{15,21}$ However, the macrophages accumulation inside and outside the fascicles in the acute phase after crush injury which does not cause a complete disconnection of nerve fibers is not yet known. Some reports based on tissue dissociation technique that did not distinguished between compartment of nerve fascicles ${ }^{14}$. Avellino et al.,${ }^{15}$ mentioned that after transection injury at the peripheral nerves, an increasing macrophage numbers start to be observed from the first day afternerve injury, and continue until day 21. Leskovar et al., ${ }^{17}$ also suggested that the macrophages accumulation in injury area occured on day 3 after a peripheral nerve crush injury. While Omura et al., ${ }^{22}$ suggested that the macrophages accumulation reached a peak after acute crush injury on day 14 after peripheral nerve injury. However, they did not differentiate the intrafascicular and extrafascicular area of the peripheral nerves as well as the proximal and distal segments of injury. Since the intrafascicular area directly influences the axonal growth cone and Schwann cells, this compartment is more important to be protected from excessive number of inflammatory cells and inflammatory cytokines especially during the regenerative phase.

Considering the important role of the macrophages in the acute phase after nerve injury; the lack of data on the percentage of macrophages inside and outside nerve fascicles in rat model of sciatic nerve crush injury; 
and the different finding of several previous studies on the number of the macrophages accumulation in acute peripheral nerve injury become the basis for this study. The purpose of this study is to determine the percentage of the macrophages inside and outside fascicles in the proximal segments, injury segment, and distal segment after acute crush injury to the sciatic nerve.

\section{MATERIALS AND METHODS}

The research was held in the Laboratory of Histology and Cell Biology, Faculty of Medicine, Universitas Gadjah Mada. Ethical clearance (no: KE/FK/705/EC) has been approved by the ethical committee of Faculty of Medicine, Universitas Gadjah Mada.

\section{Animal model}

Thirty male Wistar rats, 3 months aged, weight 200-230 g were divided randomly into crush injury group and sham-operated group. Each group was divided into 3 subgroup, which were classified by the time of the termination after injury i.e.. day 3 , day 7 , and day 14 after crush injury. Each subgroup consists of 5 rats. Firstly, the rats were adapted to the environment for 7 days. The rats from both groups were anesthetized intramuscularly in the left thigh using ketamine-xylazin solution on day 0 after adaptation. The rats of the injury group were incised at the mid posterior right thigh to expose the sciatic nerves. The right sciatic nerve was separated from gluteal muscle and hamstring muscles, until the entry of sciatic nerve on the lower part of the leg can be seen. Crush injury was carried out at a distance of $0.5 \mathrm{~cm}$ from the location of the entry of the nerves to the muscles by clamping it with a non-serrated $3 \mathrm{~mm}$ clam with the power of approximately $5.24 \mathrm{~kg}$ for
30 seconds. The clamping was applied to each side sciatic nerve. To prevent infection, penicillin-streptomicyn was dripped on of the area around the injury. The wound was sutured with a 4.0 non-absorbed suture. To prevent infection and postoperative pain, antibiotic (amoxicillin) and analgesic (ibuprofen) containing drinking water was given ad libitum for 3 days.

\section{Perfusion, necropsy, tissue processing and imaging \\ Rats were sacrificed by transcardial} perfusion on day-3, 7 and 14. The perfusion solutions used in this study was $10 \%$ formalin in PBS solutions. Sciatic nerve was dissected out at $0.3 \mathrm{~cm}$ from crush injury area to proximal direction and $0.5 \mathrm{~cm}$ from crush injury area to the distal part. The distal part then marked with black thread. Formalinfixed paraffin embedding (FFPE) specimens were prepared in longitudinal orientation. Two slides containing $4 \mu \mathrm{m}$ thick slice of tissue specimen were prepared, and each slide was stained using hematoxylin-eosin and anti CD68 antibody (ED1, abcam 31630) respectively. The immunopositive cells were visualized using avidin-biotin Horse Radish Peroxidase (ABC kit, Biocare) followed by diaminobenzidine (DAB). The sectiones were counterstained using Hematoxylin Meyers.

The imaging was performed using Olympus CX-21 microscope, 400x magnification connected to camera and computer. The inside and outside area of the nerve fascicles were distinguished by tracing the perineurium of the undamaged proximal segment towards the distal segment. Observations were conducted on three fields of view on each area. All immunopostive and immunonegative cells of each area were counted. 


\section{Data analysis}

The percentage of immunopositive cells was calculated by dividing the number of ED1 immunopositive cells by the total number of immunopositive and immunonegative cells in each animal per area. The data was presented as mean \pm SD for each area. The difference between groups were analyzed using unpaired t test.

\section{RESULTS}

All of the rats in this study $(n=30)$ were survive until the time of termination. The macrophages were observed as large cells with rounded nuclei and brownish cytoplasm (figure 1). Macrophages were distributed inside and outside the nerve fascicles in all segments of sciatic nerves from animals terminated on day 3,7 and 14. However, at a glance, higher distribution of immunopositive cells were observed on day 3 outside the fascicle and day 7 and 14 inside the nerve fascicle especially in the injured and distal segment of the sciatic nerve. More immunonegative cells were also observed inside the nerve fascicles in the injured and distal segments on day 3 .

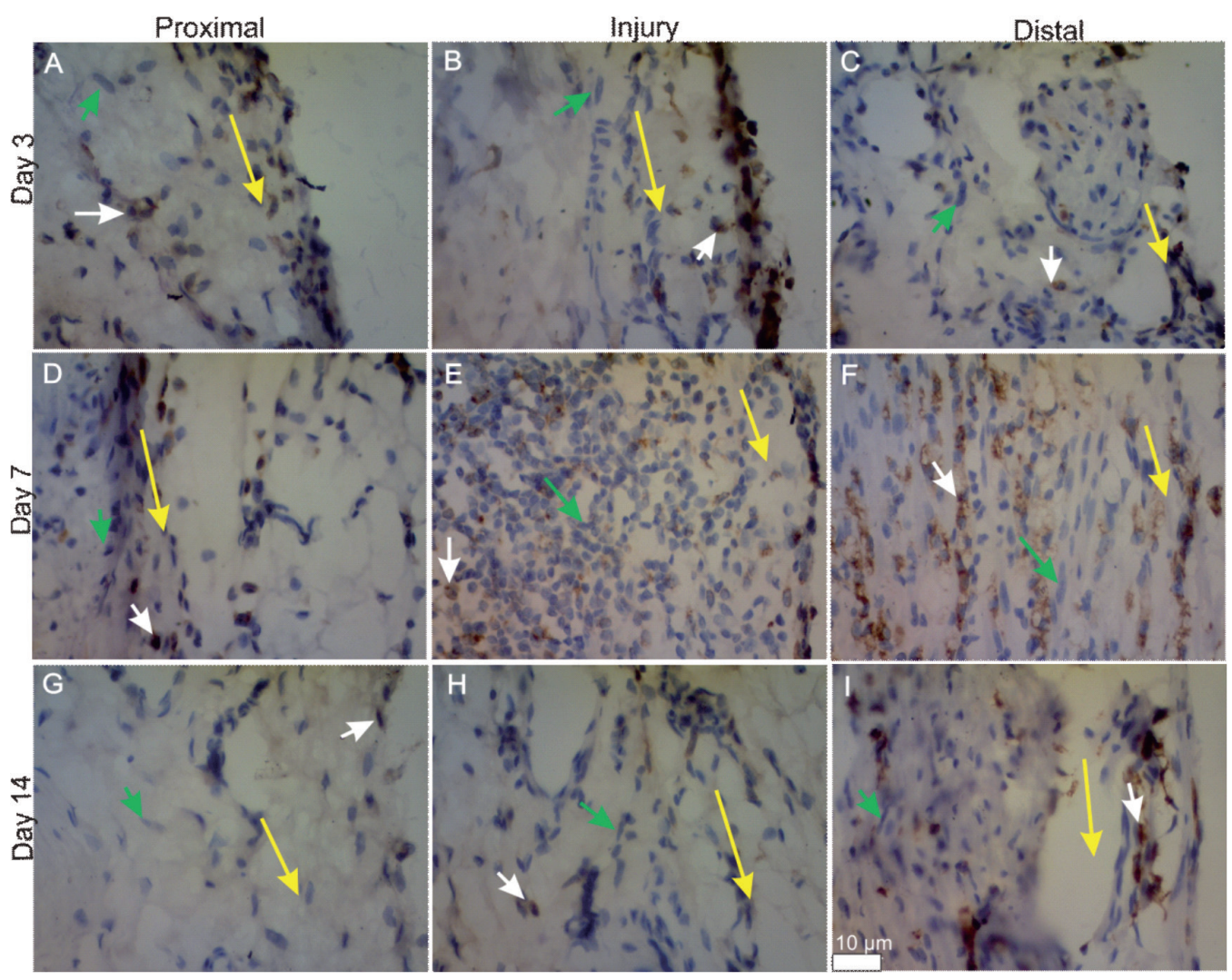

FIGURE 1. ED1 immunohistochemical by day termination groups on each segment of sciatic nerve area. (A) injury group in 3rd day of the proximal segment. (B) injury group in 3rd day of injury segment. (C) injury group in 3rd day of the distal segment. (D) injury group in 7 th day of the proximal segment. (E) injury group in 7 th day injury segment. (F) injury group in 7 th day distal segment. $(G)$ injury group in 14th day of the proximal segment. $(\mathrm{H})$ injury group in 14th day injury segment. (I) injury Group in 14th day of distal segment. The yellow arrow indicates the limits of outer and inner fascicles. White arrow indicates macrophages. Green Arrow indicates Schwann cells. At 400x magnification. On Scale of $10 \mu \mathrm{m}$. 


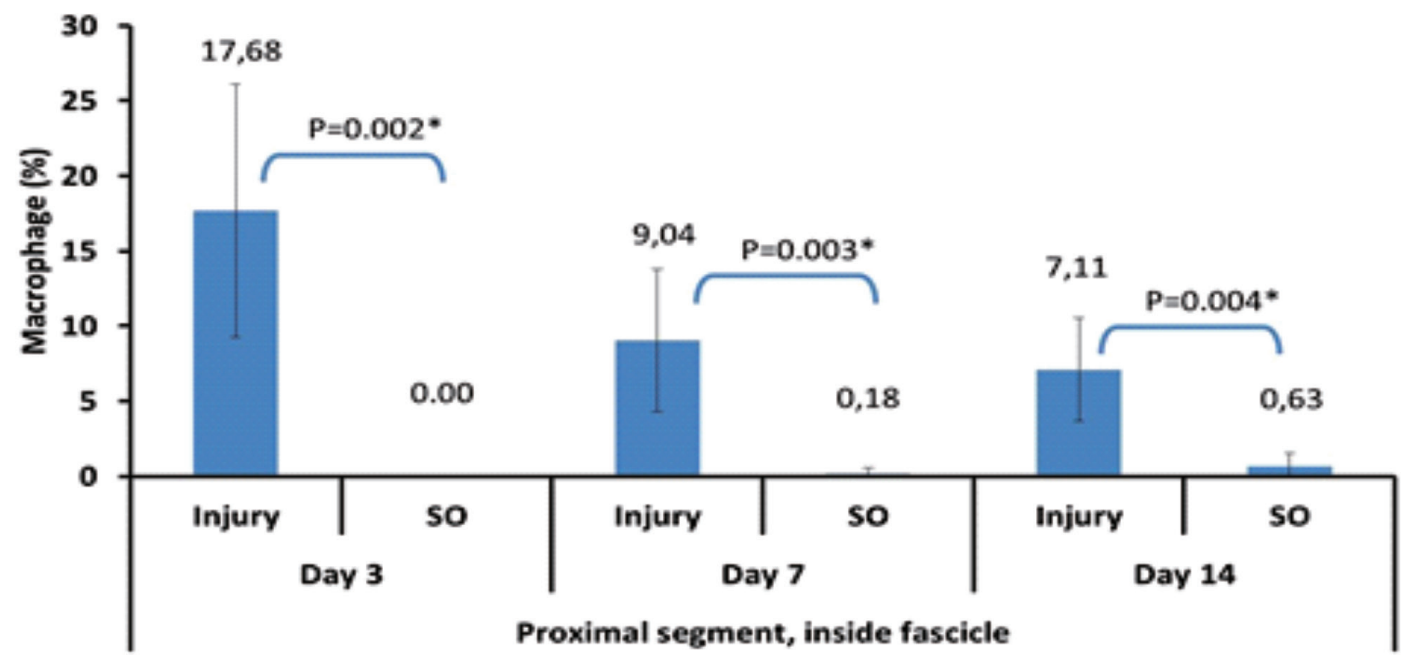

$*$ : $\mathrm{p}<0.05$, SO: Sham operation

FIGURE 2. Average percentage of macrophages in the proximal segment inside sciatic nerve fascicles by the termination day. $\mathrm{X}$ axis shows the injury group and sham operation by the termination day. $\mathrm{Y}$ axis shows the average percentage of macrophages (\%).

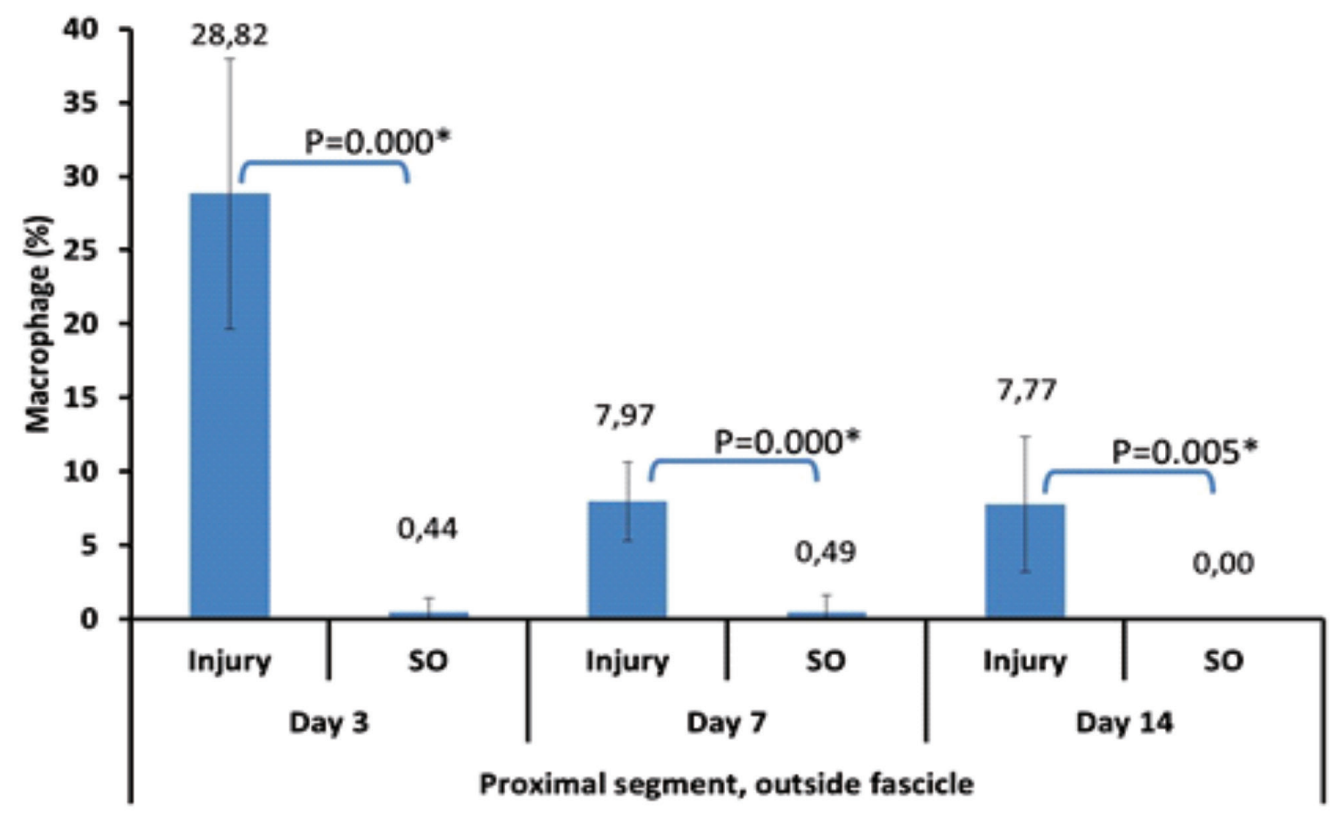

$*: \mathrm{p}<0.05, \mathrm{SO}$ : Sham operation

FIGURE 3. Average percentage of macrophages in the proximal segments outside the sciatic nerve fascicles by the termination day. $\mathrm{X}$ axis shows the injury group and sham operation by the termination day. Y axis shows the average percentage of macrophages (\%). 
The percentage of macrophages in each segments and area was presented in figure 2-7. The counting of immunopositive cells revealed that the mean percentage of macrophages is higher at day 3 and still higher at day 7 and 14 after acute crush injury in the injury group compared to sham operation group in all segments and compartment. The mean percentage of macrophages inside and outside nerve fascicles of proximal segment reached the peak on day 3 after the sciatic nerve crush injury and then decreased on day 7 and 14 (figure 2,3).

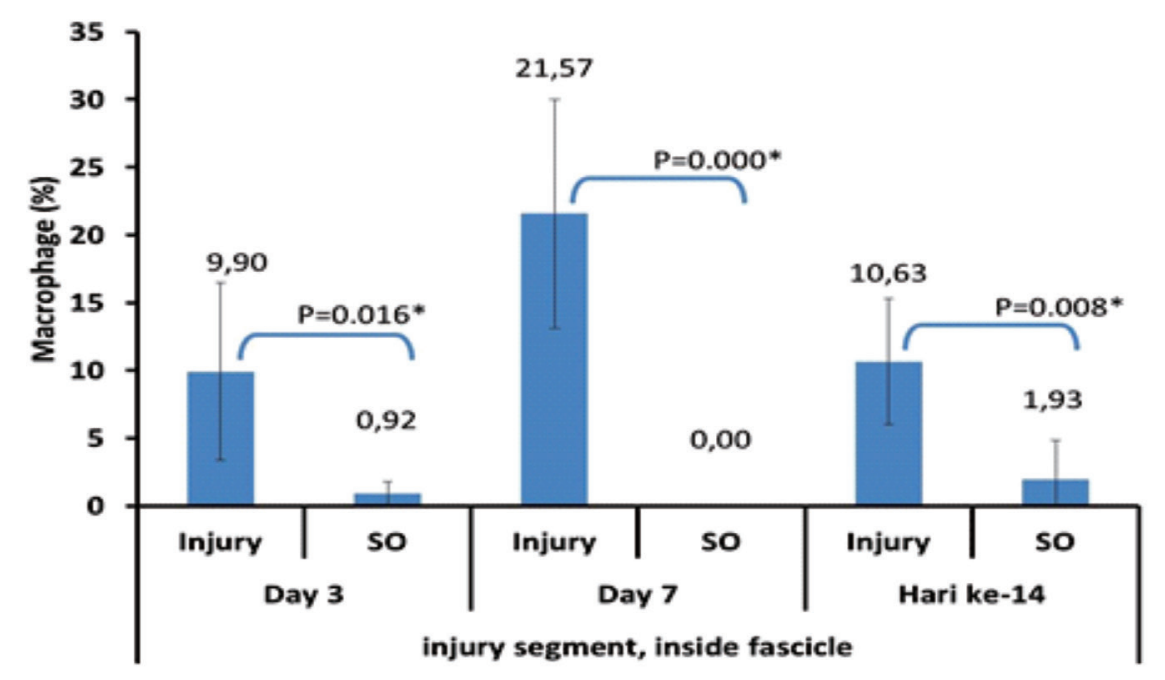

$*: \mathrm{p}<0.05$, SO: Sham operation

FIGURE 4. Average percentage of the macrophages number in the injury segment inside the sciatic nerve fascicles by the termination day. $\mathrm{X}$ axis shows the injury group and sham operation based on the termination day. $\mathrm{Y}$ axis shows the average percentage of macrophages $(\%)$.

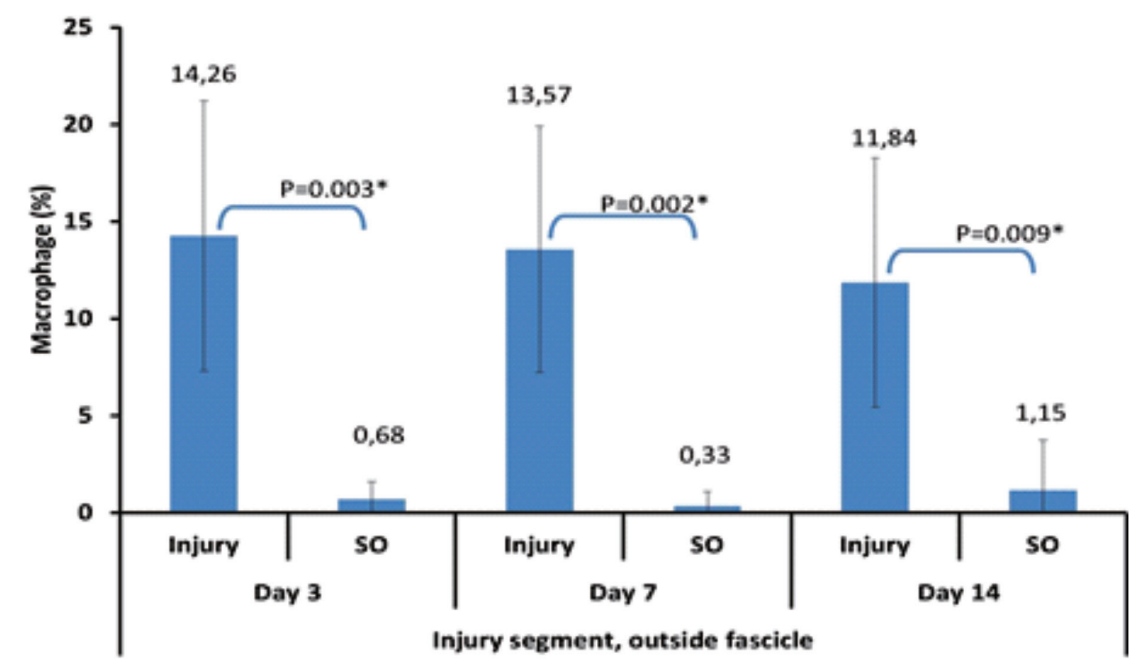

$*: \mathrm{p}<0.05$, SO: Sham operation

FIGURE 5. Average percentage of the macrophages number in the injury segment outside the scaitic nerve fascicles by the termination day. $\mathrm{X}$ axis shows the injury group and sham operation based on the termination day. $\mathrm{Y}$ axis shows the average percentage of macrophages (\%). 
The peak of macrophages number in the injury segment inside fascicles occurred on day 7 , then decreased on day 14 (figure 4) . While, on the injury segment, outside the nerve fascicles, the peak of macrophages percentage occurred on day 3 after nerve crush injury and then decreases consecutively on day 7 and 14 (figure 5). Similar results were found in the distal segments (figure 6,7).

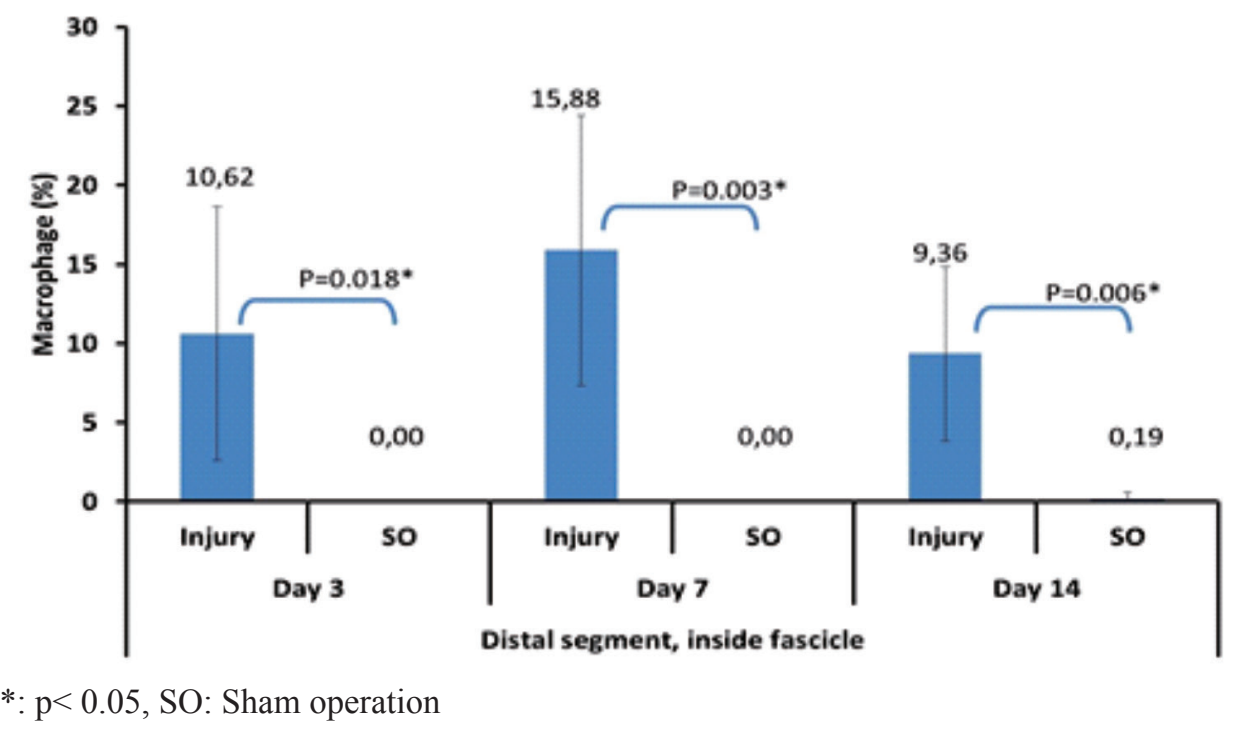

FIGURE 6. Average percentage of the macrophages number in the distal segments inside sciatic nerve fascicles based on the termination day. $\mathrm{X}$ axis shows the injury group and sham operation based on the termination day. $\mathrm{Y}$ axis shows the average percentage of macrophages (\%).

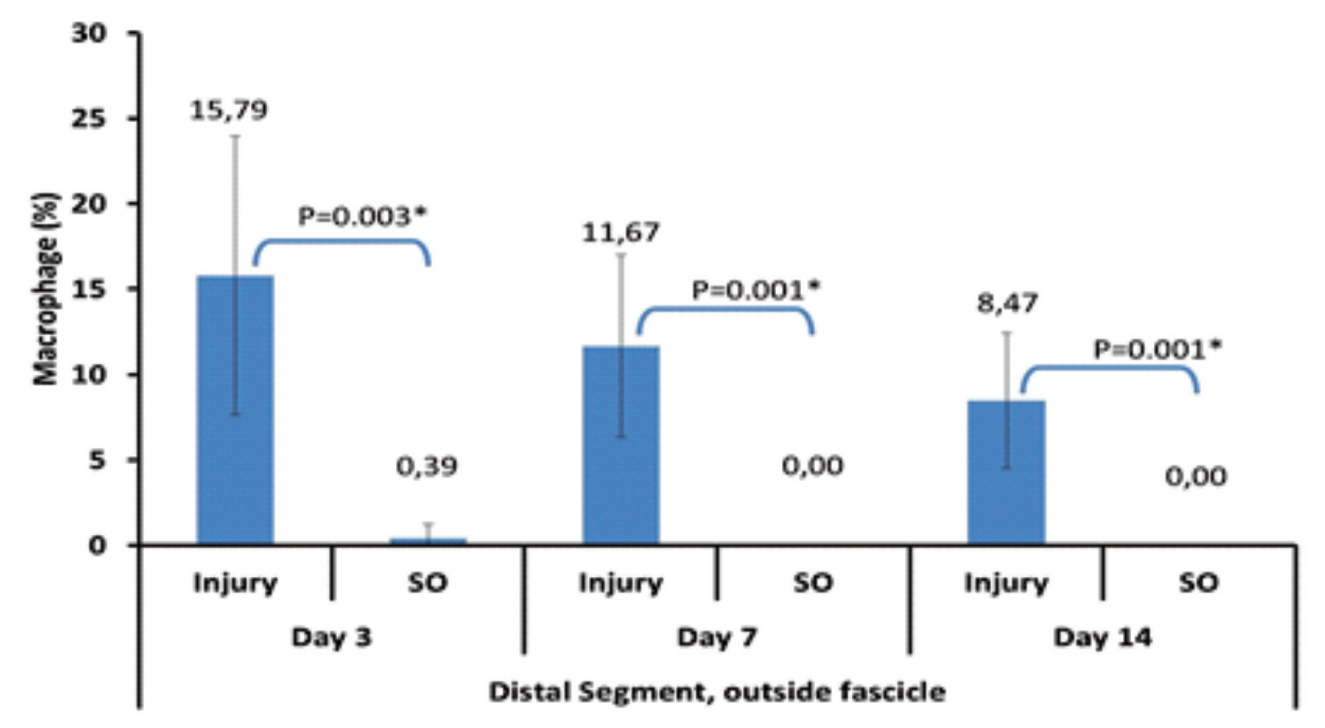

*: $\mathrm{p}<0.05$, SO: Sham operation

FIGURE 7. Average percentage of the macrophages number in the distal segment outside the sciatic nerve fascicles based on the termination day. $\mathrm{X}$ axis shows the injury group and sham operation based on the termination day. $\mathrm{Y}$ axis shows the average percentage of macrophages (\%). 


\section{DISCUSSION}

In general, the percentage of the macrophage in crush injury group was higher compared to the ones in the sham-operation group in all segments (i.e. proximal, injury and distal); all compartment (inside and outside nerve fascicle) at all termination day (3,7 and 14). This study showed that the peak percentage of macrophages outside the nerve fascicles at the proximal segment, distal segment and injury segment on day 3 after peripheral nerve crush injury was higher compared to the ones inside nerve fascicles. The results are consistent with the report by Taskinen et al., ${ }^{21}$ which mentioned that the peak accumulation of macrophages in the proximal segment's epineurium occurs on day 3 after peripheral nerve injury. Since the epineurium also got damaged upon crush injury and they have more blood vessels compared to intrafascicular compartment, the macrophages accumulated more in the epineurium at the beginning of injury.

On day 7 and day 14 the average percentage of macrophages in those three segments outside nerve fascicles decreased. The clearance of cell debris by phagocytes may already be almost completed by day 7 and the macrophages are no longer needed in this compartment as much as at the begining of the injury. On day 7 and 14 after crush injury of the peripheral nerve, nerve-blood barrier also has been compromized. Due to damage to this blood-nerve barrier, macrophages which previously accumulated outside the nerve fascicles may then entered into intrafascicular compartment. However, this notion still need further elucidation. These macrophages then will perform their function to phagocytose the myelin debris that need longer time due to its dense molecular content. ${ }^{22}$
This study showed that the peak percentage of the macrophages inside the fascicle at the proximal segment was on day 3 and decreased on day 7 and 14. This result is different from the report by Taskinen et al., ${ }^{21}$ which stated that the peak of macrophages accumulation in the proximal segment's endoneurium is on day 7. Moreover, the results of this study were also different from the results from Avellino et al. ${ }^{15}$ which showed that the accumulation of the intrafascicular macrophages reached the peak on day 21 after injury. However, their results did not diferentiate the proximal, injured and distal segments. The proximal segments have more intact blood vessels compared to injured and distal segment that enable circulated macrophages to enter the nerve fascicle at earlier phase after injury.

On day 7 after injury, the mean percentage of the macrophages in proximal segments decreased, probably due to the migration of the macrophages to the more distal segments of the nerves to phagocyte the myelin debris. The macrophage migration is also presumably caused by the higher expression of cytokines and chemokines at the injured segment than the other segments. ${ }^{17,21,22 \text { While on }}$ day 14 , the average percentage of the macrophages decreased presumably due to the restoration of the blood nerve barrier and some of the macrophages underwent apoptosis after performing their function. Nerve-blood barrier restoration was started from the proximal segment to more distal segment. ${ }^{22,26}$

${ }^{\text {In }}$ side the nerve fascicle at the injury and distal segments, macrophages reached the peak percentage on day 7 and more macrophages could be found inside the nerve fascicles compared to the ones at the epineurium. Blood-nerve barrier starts to be compromized on day 3 after nerve injury. ${ }^{21,22}$ Omura et $a l . .^{22}$ mentioned that after nerve injury, the blood nerve barrier will damage, 
especially on day 3 to day 7 , and it occurs especially at a distance of $0-15 \mathrm{~mm}$ from the peripheral nerve crush injury. The blood nerve barrier damage induced the peak percentage of macrophages in the injured nerve fascicles. The consequences of the damage and the inflammatory mediators production were the migration of the macrophages from the circulation to the endoneurium; the phagocytosis of the myelin debris; and releasing pro-inflammatory mediators.

The macrophage invasion from outside the fascicles and from the proximal segments will lead to the increasing number of macrophages in endoneurium of injured and distal segments at day 7. This study is slightly different from the results obtained by Taskinen et al. ${ }^{21}$ which states the peak accumulation of endoneurial macrophages in the distal segment is on day 14. The use of different models of injury may become the basis of this discrepancy. The study conducted by Taskinen et al., ${ }^{21}$ used a transection injury model that produce more severe injury. Due to this transection injury, the blood nerve barrier recovery will take longer compared to the one with the crush injury model, so until on day 14 there will be a lot of macrophages accumulation inside the fascicles on transection injury. ${ }^{1}$

The peak percentage of the intrafascicular macrophages on the day 7 is also probably due to the local activation of resident macrophages. Local macrophages express major histocompatibility complex (MHC) and complement receptors. They are activated and proliferated before the arrival of monocytes from blood circulation that eventually differentiated into active macrophages. ${ }^{5,7,24}$ The macrophages phagocyte myelin debris, followed by releasing antiinflammatory mediators to provide space for the nerve regeneration. ${ }^{6}$ The macrophages later differentiate into the M2 subtype, and played role in supporting peripheral nerve regeneration by releasing some antiinflammatory mediators such as IL-10.6,24,25

${ }^{\text {After }}$ nerve injury occurred, mast cells release histamine that causes dilation of capillary and increase the permeability of blood vessels that lead to the invasion of inflammatory cells including macrophages from the circulation. ${ }^{14}$ The migration of macrophages is strongly related with the expression of cytokines and chemokines which very high at the beginning of injuries, especially on the first day of nerve injury. Schwann cells and fibroblast cells releases chemokines such as MCP-1 and MIP$1 \alpha{ }^{27}$ Perrin et al.,${ }^{28}$ also stated on the first day and the beginning of peripheral nerve injury there is an increase of MCP-1 and MIP- $1 \alpha$ on distal segments and injury segments.

On day 14 in the injured and distal segment, the mean percentage of the macrophages started to decline. It may be due to apoptosis of macrophages after performing their function. ${ }^{26 \text { Blood nerve barrier }}$ also started to proceed the restoration process on day $14 .^{22}$ These mechanisms are believed to be the protection mechanism against excessive inflammatory response, because excessive accumulation of the macrophages may produce cytotoxic effect and inhibit nerve regeneration. . $^{1929}$ However, there is a report that macrophages still being recruited even though the nerve has started the nerve regeneration process. ${ }^{22}$ This notion is supported by the report that TNF- $\alpha$ and IL$1 \beta$ increase after on day 14 nerve transection injury $^{28}$. The more severe damage caused by transection injury may induce prolonged accumulation of inflammatory cells that may compromize the regeneration process.

Our result also showed that the mean percentage of the macrophages on the day 14 were still high compared to the one in the sham operation group. On the other hand, at the distal segment at day 14, the percentage 
of macrophage inside the fascicle is higher than its percentage outside the fascicle. It is probably caused by the accumulation of macrophages at local endoneurium and in circulation due to a longer restoration of blood nerve barier in distal segment. ${ }^{22}$

The dynamic of macrophages distribution among the different segment of nerve injury and different compartment of peripheral nerve is presumably caused by the different expression of cytokines and chemokines on these segments and compartment. However, the cytokines and chemokines level in each segment and compartment still need to be investigated further. Only limited data can be found in the literature i.e. Leskovar et al., ${ }^{17}$ stated that the increasing TNF- $\alpha$ and IL-1 occurs at the beginning of the peripheral nerve injury, with higher expression at the segment near injury compared to the distal segment.

\section{CONCLUSIONS}

The peak percentage of the macrophages at the extrafascicular compartment in all segments of the peripheral nerve and intrafascicular compartement in proximal segments occurs at day 3 after crush injury. The peak percentage of macrophages at the intrafascicular compartment in injury and distal segments occurs at day 7 .

\section{ACKNOWLEDGEMENTS}

The authors would like to thank Drs. Mustofa, Ginus Partadiredja, Dwi Nur Ahsani as well as all faculty members of Department of Histology and Cell Biology Faculty of Medicine Universitas Gadjah Mada for valuable discussion. We also thanks Mr. Y. Suhardi, Mrs. Wiwit Setyowati and Mrs. Sumaryati for excellent technical assistance.

\section{REFERENCES}

Burnett MG, Zager EL. Pathophysiology of peripheral nerve injury: a brief review. Neurosurg Focus 2004; 16(5):1-7.

Moalem-Taylor G, Austin PJ. The neuro-imune balance in neuropathic pain: involvement of inflammatory imune cells, imune-like glial cells and cytokines. J Neuroimunol 2010; 229(1-2):26-50.

Kiguchi N, Kobayashi Y, Kishioka S. Chemokines and cytokines in neuroinflammation leading to neuropathic pain. Curr Opin Pharmacol 2012; 12(1):55-61.

Stoll G, Jander S, Myers RR. Degeneration and regeneration of the peripheral nervous system: from Augustus Waller's observations to neuroinflammation. J Peripher Nerv Syst 2002; 7(1):13-27.

Gaudet AD, Popovich PG, Ramer MS. Wallerian degeneration: gaining perspective on inflammatory events after peripheral nerve injury. J Neuroinflammation 2011; 8(110):1-13.

Rotshenker S. Wallerian degeneration: the innateimune response to traumatic nerve injury. $\mathrm{J}$ Neuroinflammation 2011; 8(109):1-14.

Hall S. The response to injury in the peripheral nervous system. J Bone Joint Surg Br 2005; 87(10):130919.

Rosenberg AF, Wolman MA, Franzini-Armstrong C, Granato $\mathrm{M}$. In vivo nerve-macrophage interactions following peripheral nerve injury. J Neurosci 2012; 32(11):3898-909.

Vargas ME, Barres BA. Why is Wallerian degeneration in the CNS so slow?. Annu Rev Neurosci 2007; 30:153-79.

Shamash S, Reichert F, Rotshenker S. The cytokine network of Wallerian degeneration: tumor necrosis factor- $\alpha$, interleukin- $1 \alpha$, and interleukin1ß. J Neurosci 2002; 22(8):3052-60.

Shubayev VI, Angert M, Dolkas J, Campana WM, Palenscar K, Myers RR. TNF- $\alpha$ induced MMP-9 promotes macrophages recruitment into injured peripheral nerve. Mol Cell Neurosci 2006; 31(3):407-15.

Nadeau S, Filali M, Zhang J, Kerr BJ, Rivest S, Soulet $\mathrm{D}$, et al. Functional recovery after peripheral nerve injury is dependent on the pro-inflammatory cytokines IL-1 $\beta$ and TNF: implications for neuropathic pain. J Neurosci 2011; 31(35):1253342. 
Murray PJ, Wynn TA. Protective and pathogenic functions of macrophage subsets. Nat Rev Immunol 2012; 11(11):723-37.

Ydens E, Cauwels A, Asselbergh B, Goethals S, Peeraer L, Lornet G, et al. Acute injury in the peripheral nervous system triggers an alternative macrophage response. J Neuroinflammation 2012; 9(176):1-17.

Avellino AM, Hart D, Dailey AT, MacKinnon M, Ellegala D, Kliot M. Differential macrophage response in the peripheral and central nervous system during Wallerian degeneration of axons. Exp Neurol 1995; 136(2):183-98.

Perry VH, Brown MC, Gordon S. The macrophage response to central an peripheral nerve injury a possible role for macrophages in regeneration. J Exp Med 1987; 165(4):1218-23.

Leskovar A, Moriarty LJ, Turek JJ, Schoenlein IA, Borgens RB. The macrophage in acute neural injury: changes in cell numbers over time and levels of cytokine production in mammalian central and peripheral nervous systems. J Exp Biol 2000; 203(Pt 12):1783-95.

Decosterd I, Woolf CJ. Spared nerve injury: an animal model of persistent peripheral neuropathic pain. Pain 2000; 87(2):149-58.

Kigerl KA, Gensel JC, Ankeny DP, Alexander JK, Donelly DJ, Popovich PG. Identification of two distinct macrophage subsets with divergent effects causing either neurotoxicity or regeneration in the injured mouse spinal cord. J Neurosci 2009; 29(43):13435-44.

Moon ML, McNeil LK, Freund GG. Macrophages make mesick: how macrophageactivation statesinfluence sickness behavior. Psychoneuroendocrinology 2011; 36(10):1431-40.

Taskinen HS, Roytta M. The dynamics of macrophage recruitment after nerve transaction. Acta Neuropathol 1997; 93(3):252-9.
Omura T, Omura K, Sano M, Sawada T, Hasegawa T, Nagano A. Spatiotemporal quantification of recruit and resident macrophages after crush nerve injury utilizing immunohistochemistry. Brain Res 2005; 1057(1-2):29-36.

Mueller M, Leonhard C, Wacker K, Ringelstein EB, Okabe M, et al. Macrophage response to peripheral nerve injury: the quantitative contribution of resident and hematogenous macrophages. Lab Invest 2003; 83(2):175-85.

Mueller M, Wacker K, Ringelstein EB, Hickey WF, Imai Y, Kiefer R. Rapid response of identified resident endoneurial macrophage to nerve injury. Am J Pathol 2001; 159(6):2187-97.

Zhang G, Hoffman PN, Sheikh KA. Axonal degeneration in dorsal columns of spinal cord does not induce recruitment of hematogenous macrophages. Exp Neurol 2014; 252:57-62.

Kuhlmann T, Bitsch A, Stadelmann C, Siebert H, Bruck W. Macrophages are eliminated from the injured peripheral nerve via local apoptosis and circulation to regional lymph nodes and the spleen. J Neurosci 2001; 21(10):3401-8.

Bendszus M, Stoll G. Caught in the act: in vivo mapping of macrophage infiltration in nerve injury by magnetic resonance imaging. J Neurosci 2003; 23(34):10892-6.

Perrin FE, Lacroix S, Aviles-Trigueros M, David S. Involvement of monocyte chemoattractant protein-1, macrophage inflammatory protein- $1 \alpha$ and interleukin-1 $\beta$ in Wallerian degeneration. Brain 2005; 128(Pt 4):854-66.

Laskin DL. Macrophages and inflammatory mediators in chemical toxicity: a battle of forces. Chem Res Toxicol 2009; 22(8):1376-85. 